\title{
Biometric characteristics of the wild population of sea urchin Paracentrotus lividus (Lamarck, 1816) on the Tunisian coast
}

\author{
F. Sellem ${ }^{1}$ (D) B. Bouhaouala-Zahar ${ }^{2}$ \\ Received: 29 September 2020 / Revised: 26 March 2021 / Accepted: 3 April 2021 / Published online: 17 April 2021 \\ (C) The Author(s) 2021
}

\begin{abstract}
The present study was conducted to provide biometric data of the edible sea urchin Paracentrotus lividus along the Tunisian coastline where thirteen marine localities were selected randomly. A total of 653 individuals were collected and their metric and weight measurements were recorded. The size distribution of the different samples was determined and relative growth expressions were deduced. Data analysis showed that all localities' samples of the wild population were dominated by one-size class, except Port Prince and Haouaria. Interestingly, only diameter-height relationships (D-H) were different between the geographical localities. Diameter-weight relationships (D-TW and D-TWTE) revealed a significant negative growth for all the localities, with the exception of Gammarth which showed positive growth for total weight (D-TW). Moreover, the multivariable analysis revealed divergences and/or similarities between metric and weight variables. Altogether, data highlights the inter-population discrimination with respect to geographic localization and clear segregation between the northern and the eastern localities demonstrated the plasticity of the species.
\end{abstract}

Keywords South Mediterranean $\cdot$ Tunisia $\cdot$ Sea urchin $\cdot$ Biometrics

\section{Introduction}

Nowadays, edible species of echinoids have a great economic interest due to the development of fishing activities (Ourens et al. 2015). The purple sea urchin Paracentrotus lividus (Lamarck, 1816) is a case study. In the Mediterranean, $P$. lividus is an emblematic species widely distributed along the Mediterranean and the northeastern Atlantic coasts. Species are encountered mainly in rocky shores and seagrass meadows (Tomas et al. 2004). It is present from the intertidal zone up to $-80 \mathrm{~m}$ and its density decreases with depth (Lecchini et al. 2002). P. lividus is the main herbivore (Sala and Zabala 1996). Through grazing, species have an important ecological role in coastal marine ecosystems and in controlling benthic algal communities (Guidetti et al. 2004; Guidetti

F. Sellem

feriel.sellem@instm.rnrt.tn

1 Laboratoire sciences halieutiques, Institut National des Sciences et Technologies de la Mer, 28, rue du 2 mars 1934, 2025 Tunis, Tunisia

2 Laboratoire des venins et molécules thérapeutiques, Institut Pasteur de Tunis, Université de Tunis El Manar, 1068 Tunis, Tunisia and Dulcic 2007; Bulleri 2013). Furthermore, these particular species are also harvested for their gonad by professional fishing, recreational fishing and illegal harvesting (Loi et al. 2017). As a result, some regions display overexploitation. Protective measures have been taken in some EU countries where species are considered as preserved symbols. Since 1996, P. lividus have been included in the protocol for the conservation of biodiversity (Annex III of the Barcelona Convention) as a marine species whose exploitation is regulated. A regional decree of fishing is usually practiced in France (Loi et al. 2017) and Italy (Gianguzza et al. 2006). The harvesting of species is being regulated i.e., reconsidered fishing period, catch quotas, and minimum harvestable size.

In this context, many local populations of $P$. lividus along the northern part of the Mediterranean and Atlantic coasts have been investigated (Sala et al. 2012; Jacinto et al. 2013; Vafidis et al. 2019). Biology of the sea urchin P. lividus has been the subject of a great deal of research, and studies have mainly focused on the reproductive cycle (Vafidis et al. 2019), growth (Lozano et al. 1995), biometric traits (Regis 1981) and the dynamic of population and stock management (Guinda et al. 2016). On a large geographical scale, the results revealed variability in the biological traits of species. In literature, reproduction does not have the same pattern. Lozano et al. (1995) and Loi et al. (2017) reported a single spawning season 
for P. lividus in Spain and Corsica, while Fernandez and Boudouresque (1997) and Guettaf et al. (2000) recorded two periods in France and Algeria. In regard to growth, the individuals reached ten years of age in Spain (Ouréns et al. 2013; Turon et al. 1995). While in other regions, the maximum age was seven to eight years in Ireland, Tunisia and Portugal (Crapp and Willis 1975; Sellem et al. 2000; Gago et al. 2003). Biometric and morphological traits vary according to geographical localities. Changes in the morphological and physiological traits of sea urchin (the weight of the gonad, intestine, lantern, length and body size) were observed during a decrease in food availability (Ebert 1996). The abiotic and biotic environmental factors have an important effect and are often involved in changes. Food availability, fishing and pollution, for example, were factors. Size change tests with sea urchin species, in particular, have been reported by several authors. Fernandez and Boudouresque (1997) have shown that when food resources are limited in lagoon tests, decline in size. Guinda et al. (2016) indicated that $76 \%$ of the stock of commercial individuals is composed of smaller average sizes in the coastal region of Cantabria (Spain) where sea urchins are exploited. In Portugal, Bertocci et al. (2013) reveal that the harvest was associated with a significant reduction in the abundance of commercially valuable individuals. Finally, on Ustica Island (Sicily) Gianguzza et al. (2006) underlined the role of regulated fishing in maintaining sea urchin populations at such low densities that no interspecific competition is induced with Arbacia lixula.

In contrast, the southern shores of the Mediterranean remain insufficiently studied despite the presence and large concern for these species. Along the African coast, species have been considered in some works in Morocco (Bayed et al. 2005), Algeria (Guettaf et al. 2000), Tunisia (Sellem et al. 2000) and Egypt (Elmasry et al. 2015), but information about population traits are scarce. Throughout the Tunisian shallow coastal waters, $P$. lividus is the predominant sea urchin species encountered. Commercial interest in this species is particularly increasing and only a few harvesting conditions have been established temporarily (in 2000). No official regulations are set up and the regulations are applied scientific data known as basic knowledge for halieutic resources. Biometry, reproduction, growth and population dynamic information are needed. Studies about growth and reproduction regarding the $P$. lividus species are limited to the northern coasts (Sellem et al. 2000; Sellem and Guillou 2007). On the other hand, investigations from biometric traits and population structures on the Tunisian coast are rare. Only Deli et al. (2017) have explored some morphological divergence of the species across the African Mediterranean coast. Given the scarcity of information on the P. lividus population in Tunisia, this study is devoted to the biometric characterization and structure of the species population along the Tunisian shore. A sampling campaign carried out in thirteen geographical locations allowed the collection of specimen size ranging from $25.2-67.9 \mathrm{~mm}$. Biometric relationships using size and weight data were established and population structure was determined. Finally, results were compared to discern the variations and similarities between samples.

\section{Materials and Methods}

\section{Study Area and Sample Collection}

This study was carried out on the Tunisian shore, located on the central part of the South Mediterranean coast. Due to its geographical location, Tunisia's climate is essentially influenced by types of winds. The northern coast is exposed to mild and humid sea winds which cause a significant drop in temperatures and an increase in precipitation. Contrastingly, in the south of the country, winds are dry causing a rise in temperatures (Ben Ismail et al. 2012). P. lividus is a preponderant sea urchin on the shallow rocky shore (Sellem et al. 2011). To scan the spatial distribution of $P$. lividus, exploration was spread over the four geographical areas of the coast corresponding to the regional divisions (northern coast, gulf of Tunis, gulf of Hammamet and gulf of Gabès), between April and May 2011. The surveys were carried out at random close to the coastline where thirteen samples of sea urchins affiliated with thirteen geographical localities were sampled.

Sea urchins were collected at random in a sampling surface not exceeding $100 \mathrm{~m} 2$ in each of the different localities: Tabarka (ta), Ras Angela (ra), Sounine (so), Gammarth (ga), Port Prince (pp), Haouaria (ha), Kelibia (ke), Maamoura (ma), Hergla (he), Monastir (mo), Mahdia (mh), Kerkenah (kr) and Jerba (je) Fig. 1. Samples were gathered on rock substrate covered with algae between 2 and $5 \mathrm{~m}$ depth. In total, 653 specimens of $P$. lividus were used for this study.

\section{Data Analysis}

In the laboratory, the specimens were drained on absorbent paper for $10 \mathrm{~min}$. The immediately-drained total weight (TW) was measured with an electronic balance $(0.01 \mathrm{~g})$. Two metric measurements were made using a digital vernier calliper $(0.1 \mathrm{~mm})$. The diameter size (D) perpendicular to the oralaboral axis) and the height ( $\mathrm{H}$ by oral-aboral axis) were measured (excluding spines). Subsequently, sea urchins were dissected to remove all the contents of the coelomic cavity and release the skeletal parts, including the test (with spines) and Aristotle's lantern. All the skeletal parts (TWTE) were dried at $70{ }^{\circ} \mathrm{C}$ for $48 \mathrm{~h}$ and then weighed. The samples of the recorded localities were grouped by size classes and represented by 
Fig. 1 Sampling localities of the studied sea urchin Paracentrotus lividus from Tunisia coasts ta Tabarka, ra Ras Angela, so Sounine, ga Gammarth, pp. Port Prince, ha Haouaria, ke Kelibia, ma Maamoura, he Hergla, mo Monastir, mh Mahdia, kr Kerkena, je Jerba

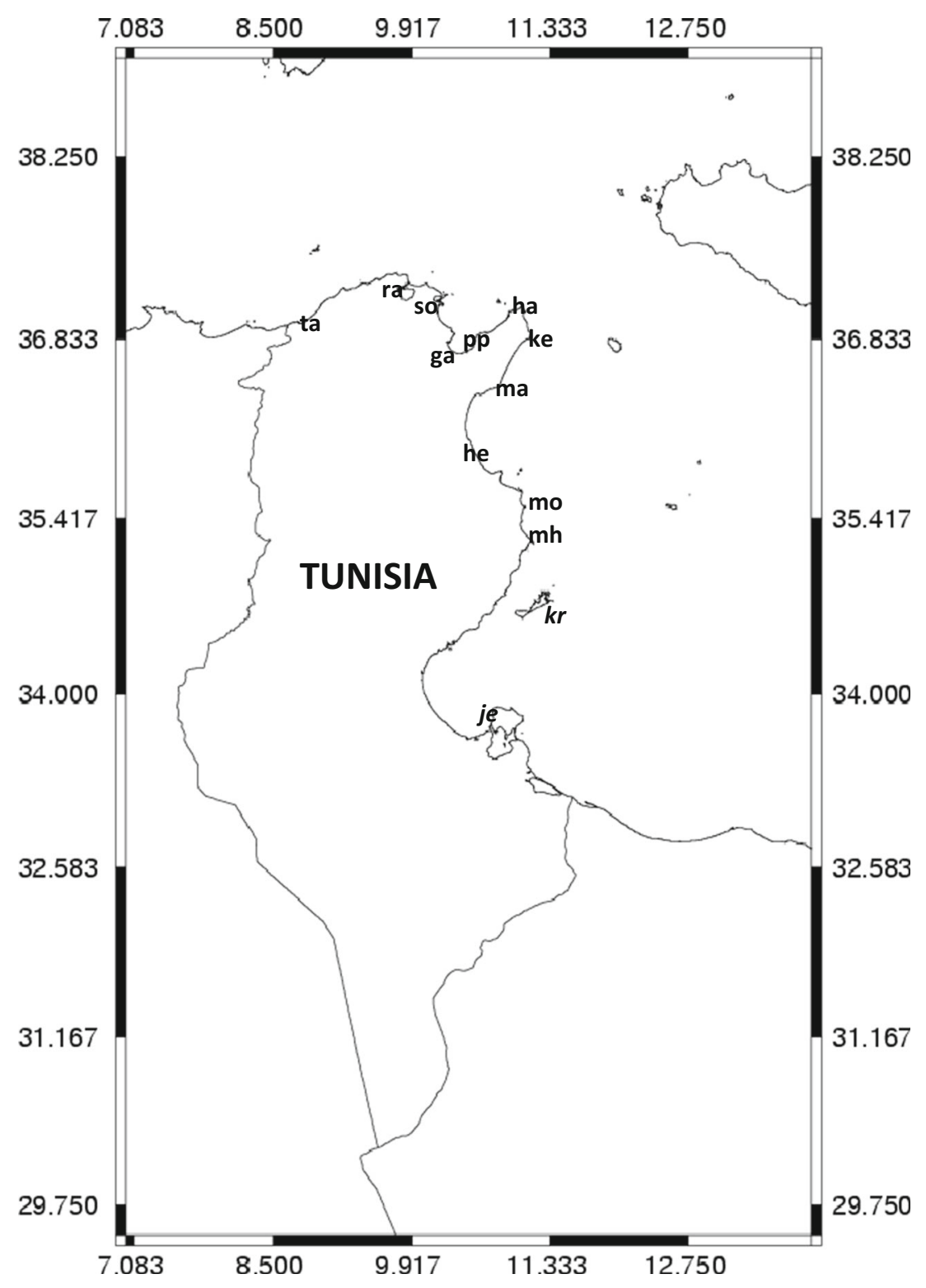

histograms. Size frequency distributions were compared using a Chi 2 test when necessary. The relative growth was investigated using diameter $\mathrm{D}$ as the reference variable. The relationship (D-H, D-TW and D-TWTE) was fitted using linear regression analysis, expressed by the eq. $\mathrm{W}=\mathrm{a}+\mathrm{b}$ (D) where (a) is the intercept of the regression and (b) is the slope which represents the growth coefficient. The b value was tested with the t-test and the differences were considered significant at $P<0.05$. One-way ANOVA was used to evaluate similarities and differences between sample variables, followed by a Tukey HSD post-hoc test. Prior to the analysis, the normality and homogeneity of variance were tested with Shapiro-Wilk and Levene tests. To discern the heterogeneity of samples within localities, factorial discriminant analysis (FDA) was conducted. All statistical analysis was performed with XLSTAT (Windows 10).

\section{Results}

\section{Size Distribution}

Thirteen samples of $P$. lividus specimen living in Tunisia's shallow coasts were investigated (Table 1). The diameter size (D) varied from 25.2-67.9 $\mathrm{mm}$. The largest specimen was found at Port Prince and the smallest was found at Sounine. The comparison of the average sizes of the diameter revealed significant differences between the thirteen localities (ANOVA, $\mathrm{F}=28.202, P<0.0001$ ). Moreover, sea urchin samples from Tabarka, Ras Angela, Sounine, Gammarth, Port Prince, Haouaria, Kelibia, Maamoura and Hergla were specified by specimens with an average diameter $\mathrm{D} \geq$ $41.9 \mathrm{~mm}$. In contrast, Monastir, Mahdia, Kerkenah and Jerba samples were characterized by a lower mean diameter 
Table 1 Biometry of Paracentrotus lividus in different geographical locality

\begin{tabular}{lccllr}
\hline Locality & $\mathrm{n}$ & $\mathrm{D} \pm \mathrm{sd}(\mathrm{mm})$ & $\mathrm{H} \pm \mathrm{sd}(\mathrm{mm})$ & $\mathrm{TW} \pm \mathrm{sd}(\mathrm{g})$ & $\mathrm{TWTE} \pm \mathrm{sd}(\mathrm{g})$ \\
\hline $\mathrm{Ta}$ & 40 & $48.07 \pm 6.45$ & $23.69 \pm 3.49$ & $39.04 \pm 14.69$ & $14.15 \pm 5.23$ \\
$\mathrm{Ra}$ & 60 & $45.66 \pm 2.7$ & $22.43 \pm 2.11$ & $34.85 \pm 5.81$ & $10.81 \pm 1.69$ \\
$\mathrm{So}$ & 42 & $44.9 \pm 5.66$ & $22.36 \pm 3.32$ & $37.98 \pm 11.92$ & $14.24 \pm 4.73$ \\
$\mathrm{Ga}$ & 47 & $47.68 \pm 3.96$ & $24.92 \pm 2.46$ & $33.98 \pm 10.7$ & $13.18 \pm 2.88$ \\
$\mathrm{Pp}$ & 63 & $50.02 \pm 8.8$ & $25.75 \pm 5.01$ & $53.49 \pm 22.12$ & $15.72 \pm 6.09$ \\
$\mathrm{Ha}$ & 75 & $48.92 \pm 6.52$ & $25.57 \pm 4$ & $33.96 \pm 8.94$ & $14.49 \pm 5.19$ \\
$\mathrm{Ke}$ & 40 & $43.75 \pm 3.49$ & $22.14 \pm 2.5$ & $33.69 \pm 6.49$ & $10.95 \pm 2.42$ \\
$\mathrm{Ma}$ & 62 & $41.95 \pm 5.52$ & $21.54 \pm 3.41$ & $27.01 \pm 6.34$ & $10.01 \pm 3.35$ \\
$\mathrm{He}$ & 48 & $41.93 \pm 6.43$ & $20.52 \pm 3.62$ & $29.27 \pm 11.94$ & $9.97 \pm 3.73$ \\
$\mathrm{Mo}$ & 42 & $39.8 \pm 4.82$ & $20.51 \pm 2.67$ & $25.61 \pm 9.54$ & $8.65 \pm 3.26$ \\
$\mathrm{Mh}$ & 44 & $38.22 \pm 3.74$ & $20.97 \pm 2.26$ & $20.75 \pm 5.08$ & $6.70 \pm 1.91$ \\
$\mathrm{Kr}$ & 47 & $38.64 \pm 4.89$ & $19.75 \pm 3.08$ & $24.07 \pm 8.07$ & $8.56 \pm 2.71$ \\
$\mathrm{Je}$ & 43 & $39.86 \pm 3.63$ & $20.15 \pm 1.59$ & $25.47 \pm 4.98$ & $7.77 \pm 1.59$ \\
\hline
\end{tabular}

$n$ number, $D$ diameter, $H$ hight, $T W$ total weight, TWTE total weight test, $s d$ standard deviation that ranged between 36.5 and $39.9 \mathrm{~mm}$. Nine size classes were defined, according to the test diameter, without spines (means: $32,37,42,47,52,57,62$ and $67 \mathrm{~mm}$ ). It is worth noting that all samples showed a diameter distribution with one mode (42 or $47 \mathrm{~mm}$ ), whereas only Port Prince and Haouaria samples showed two modes at the level of 42 and $52 \mathrm{~mm}$ (Fig.2). Recruits (small sea urchins $<20 \mathrm{~mm}$ ) were not observed during the sampling period in all localities. The juveniles, $(20-$ $30 \mathrm{~mm}$ ) corresponding to 22 and 27 classes, were identified at Port Prince, Hergla and Kerkenah with very low frequencies, which did not exceed $7 \%$ at Kerkenah, as an example. The individuals from size (30-40 mm) corresponding to classes 32 to 37 were observed in all localities with frequencies ranging from $2.12 \%-86.0 \%$. The sized sea urchins $(40-50 \mathrm{~mm}$ ) corresponding to classes 42 to 47 are also represented in all sampled localities with more than $50 \%$ of the individuals at the levels of Tabarka, Ras Angela, Sounine, Gammarth, Kelibia, Maamoura and Hergla. Finally, large sea urchins (>50 mm) corresponding to classes $52,57,62$ to 67 are only well represented in Port Prince and Haouaria with more than $50 \%$ of the specimens. However, in Mahdia, Kerkenah and Jerba large sizes of $P$. lividus were noticeably absent.

Furthermore, it is interesting to compare the population structure in Ras Angela and Sounine where sea urchin fishing has been carried out for ten years (Sellem et al. 2011). The analysis of temporal changes showed a significant difference in Ras Angela's and Sounine's locality structures (between May 2000 and May 2011, Chi 2 test respectively $P<0.0001$ and $P<0.0005)$. As a rational explanation, these later differences occurred due to the high dominance of specimens in the $52 \mathrm{~mm}$ size-class in May 2000 (the beginning of the fishing activity), and which were not highly significant in May 2011 (the present study). Furthermore, we noted that in 2001, the two localities presented respectively $40 \%$ and $33.89 \%$ of specimens with D > $55 \mathrm{~mm}$ while in 2011 , proportions declined to
$5 \%$ and $7.31 \%$, respectively. Likewise, both localities recorded a reduction in the mean size, reporting 45.66 and $45.38 \mathrm{~mm}$ as opposed to 49.06 and $49.32 \mathrm{~mm}$, respectively. Moreover, as noticed in the previous class, the $42 \mathrm{~mm}$ size class shows significant correlations (Chi 2 tests, $P<0.0001$ ). Contrarily, the $47 \mathrm{~mm}$ size class did not reveal significant differences in the size structure of these two localities during the two periods of investigation (Chi2 test; $P>0.05$ ).

\section{Metric and Weight Relationships}

The relationships between the variables (D-H, D-TW and DTWTE) are consigned in Table 2 and presented in Fig.3. Diameter-height (D-H) relationships from the different localities were found to be significant, and the $b$ values varied from 0.61 to 1.20 . A negative allometric growth $(P<0.001)$ was found in Monastir, Mahdia and Djerba. A significant positive relationship $(P<0.001)$ was observed in Kelibia, Maamoura and Kerkenah and finally a significant isometry $(P<0.001)$ was found in Tabarka, Ras Angela, Sounine, Gammarth, Port Prince, Haouaria and Hergla. Diameter-weight relationships (D-TW and D-TWTE) revealed a significant negative growth for all the localities, with the exception of Gammarth which showed positive growth for total weight.

\section{Comparison of Localities}

Considering the thirteen localities, both normality $(P>0.05)$ and homogeneity of variance $(P>0.05)$

Fig. 2 Paracentrotus lividus: size class distribution analysis at each locality during April to May 2011 ta Tabarka, ra Ras Angela, so Sounine, ga Gammarth, pp. Port Prince, ha Haouaria, ke Kelibia, ma Maamoura, he Hergla, mo Monastir, mh Mahdia, kr Kerkena, je Jerba. 


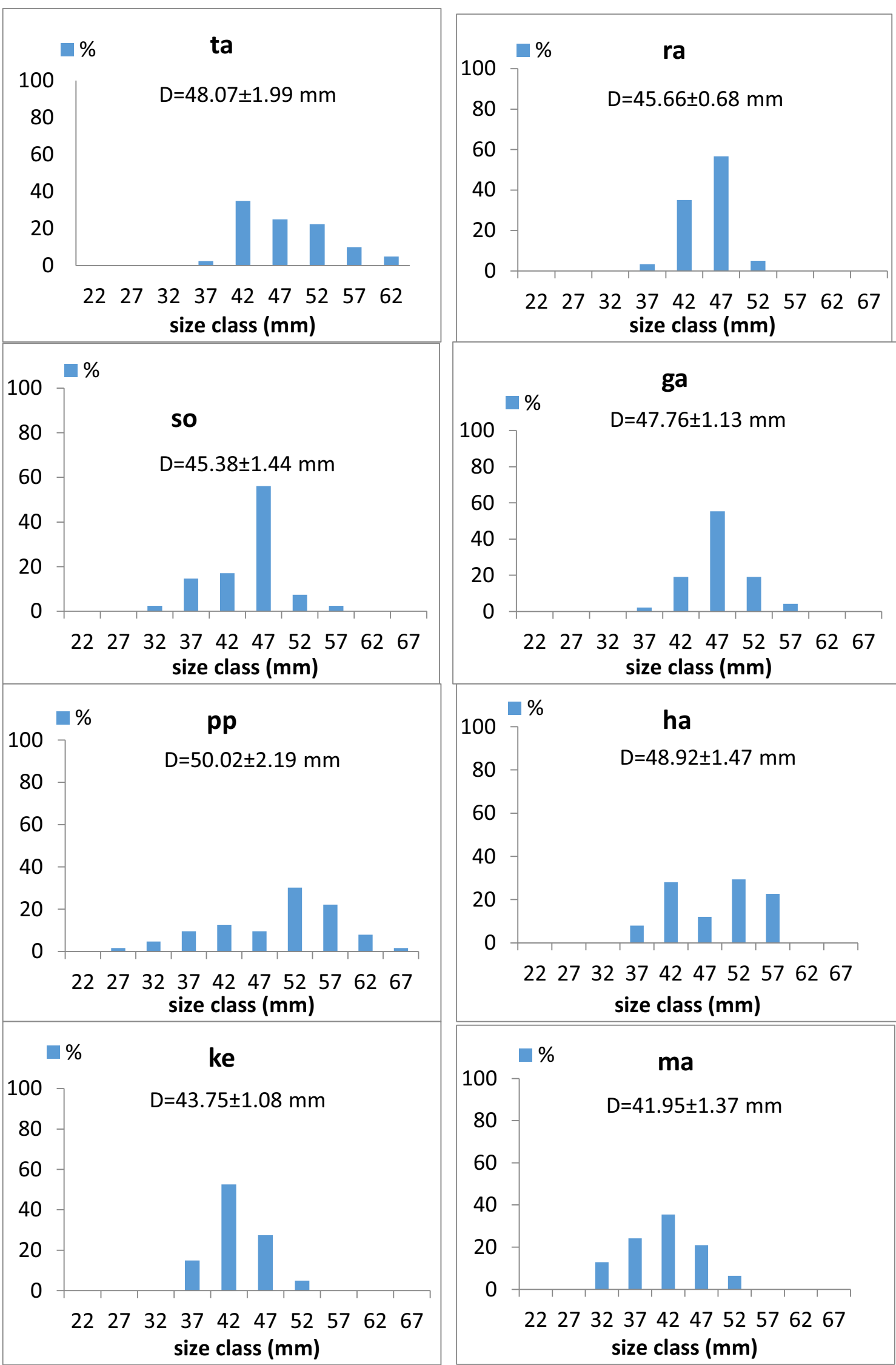




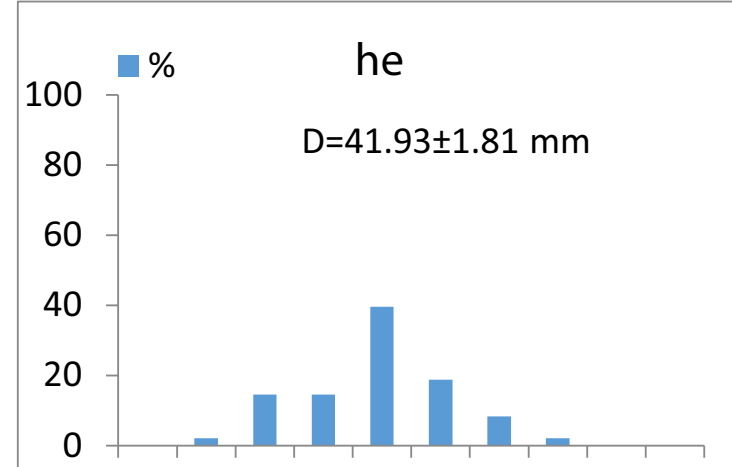

$\begin{array}{llllllllll}22 & 27 & 32 & 37 & 42 & 47 & 52 & 57 & 62 & 67\end{array}$ size class $(\mathrm{mm})$

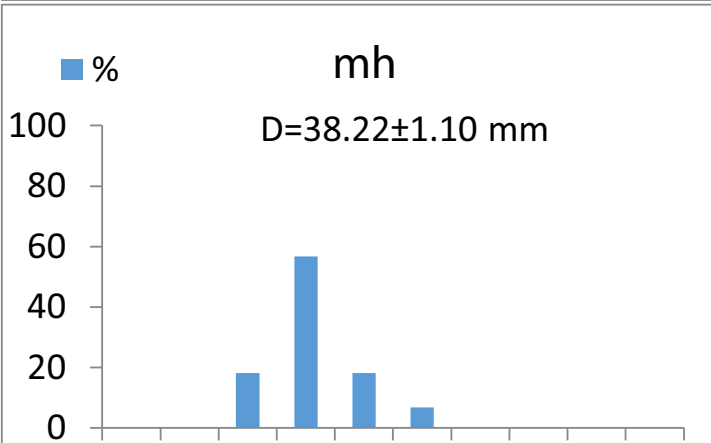

$\begin{array}{llllllllll}22 & 27 & 32 & 37 & 42 & 47 & 52 & 57 & 62 & 67\end{array}$ size class $(\mathrm{mm})$

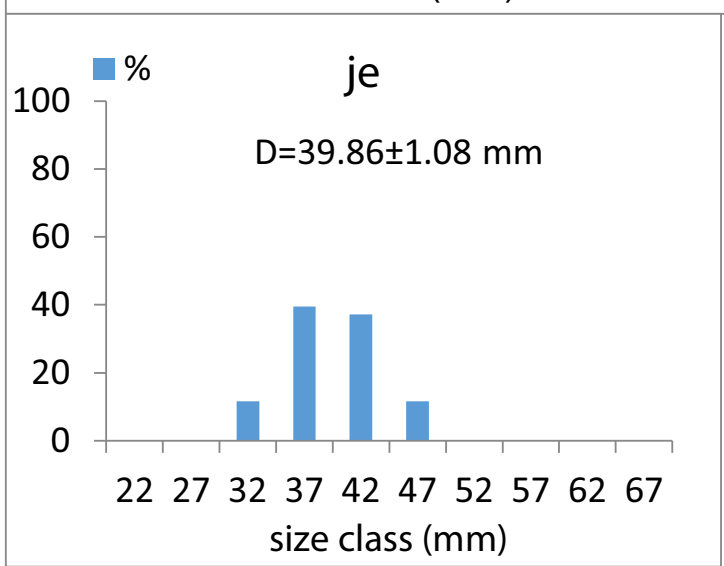

Fig. 2 (continued).

assumption of variables D, H, TW, and TWTE were satisfied. The mean values of the estimated metric and weight variables (i.e., D, H, TW, and TWTE) were presented in Table 1 . The analysis of variance showed a highly significant locality effect for all parameters $(P<0.0001)$. Multiple comparisons of averages of D, H, TW and TWTE showed a divergence between the analysed samples, and Tukey HSD clearly discriminated against the locality samples (Table 3 ). Additionally, Port Prince and Mahdia showed a highly significant difference in values of diameter and height, while the localities of Tabarka, Ras Angela, Sounine, Gammarth,

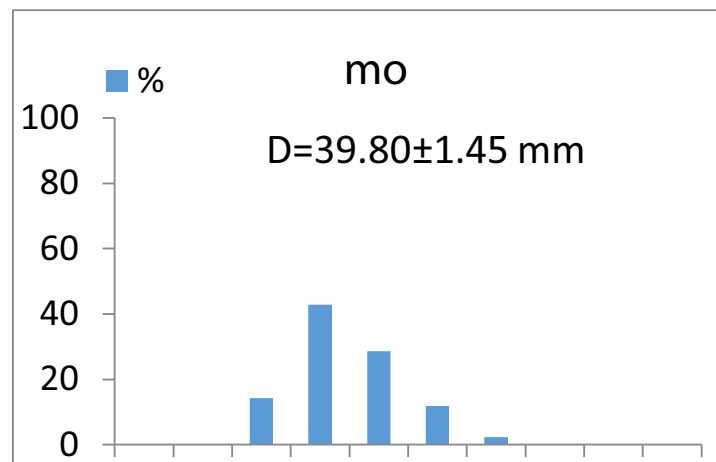

$\begin{array}{llllllllll}22 & 27 & 32 & 37 & 42 & 47 & 52 & 57 & 62 & 67\end{array}$ size class $(\mathrm{mm})$

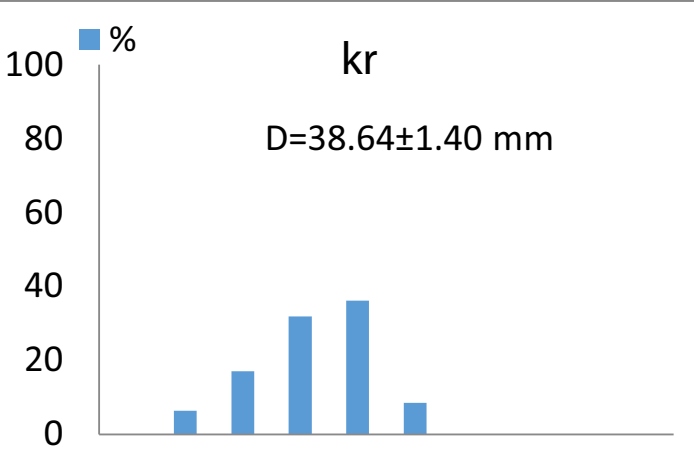

$\begin{array}{llllllllll}22 & 27 & 32 & 37 & 42 & 47 & 52 & 57 & 62 & 67\end{array}$ size class $(\mathrm{mm})$
Haouaria and Kelibia indicate significantly proximate means. This is also the case in the localities of Jerba, Kerkena, Monastir, Hergla, Maamoura and Kelibia which constitute a second collection with close significant values. For the total weight, Port Prince and Haouaria data reveals significantly equal means. Furthermore, Mahdia shows a mean total weight that is significantly different from all the localities. Finally, for the total weight test, Port Prince, Gammarth and Haouria constitute one homogenous group as their values are equal. Kerkenah also displays an average significantly different from all the localities. 
Table 2 Parameters of the relationship between (D-H), (D-TW) and (D -TWTE) for Paracentrotus lividus along Tunisia coasts

\begin{tabular}{|c|c|c|c|c|c|c|c|c|c|}
\hline \multicolumn{2}{|l|}{ Relationship } & \multicolumn{3}{|l|}{ D-H } & \multicolumn{3}{|l|}{ D-TW } & \multicolumn{2}{|l|}{$\begin{array}{l}\text { D- } \\
\text { TWT }\end{array}$} \\
\hline Locality/parameters & $\mathrm{a}$ & $\mathrm{b}$ & $\mathrm{R}^{2}$ & $\mathrm{a}$ & $\mathrm{b}$ & $\mathrm{R}^{2}$ & $\mathrm{a}$ & $\mathrm{b}$ & $\mathrm{R}^{2}$ \\
\hline Tabarka (ta) & 0.31813 & 1.0059 & 0.8403 & 2.76955 & 2.5809 & 0.8875 & 3.04576 & 2.4909 & 0.8244 \\
\hline Ras Angela (ra) & 0.45606 & 1.0882 & 0.4424 & 2.92082 & 2.6825 & 0.832 & 2.67778 & 2.2325 & 0.7103 \\
\hline Sounine (so) & 0.39416 & 1.0547 & 0.7726 & 2.79588 & 2.6312 & 0.9625 & 3.39794 & 2.771 & 0.9076 \\
\hline Gammarth (ga) & 0.29303 & 1.0076 & 0.7384 & 4.04576 & 3.3122 & 0.6664 & 2.79588 & 2.3309 & 0.78 \\
\hline Port Prince (pp) & 0.38174 & 1.0542 & 0.8841 & 2.82391 & 2.6658 & 0.9672 & 2.88606 & 2.3917 & 0.9492 \\
\hline Haouria (ha) & 0.41117 & 1.076 & 0.8409 & 1.54363 & 1.8148 & 0.8536 & 3.39794 & 2.6725 & 0.9267 \\
\hline Kelibia (ke) & 0.63227 & 1.2045 & 0.7525 & 1.92445 & 2.1 & 0.8247 & 2.76955 & 2.3126 & 0.7833 \\
\hline Maamoura (ma) & 0.47782 & 1.1152 & 0.8122 & 0.0161 & 0.8873 & 0.2677 & 2.95861 & 2.4254 & 0.8357 \\
\hline Hergla (he) & 0.38248 & 1.0437 & 0.8374 & 2.95861 & 2.7076 & 0.9647 & 3.1549 & 2.55 & 0.9595 \\
\hline Monastir (mo) & $0,10,403$ & 0.8845 & 0.6432 & 3.09691 & 2.813 & 0.833 & 3.22185 & 2.6053 & 0.7966 \\
\hline Mahdia (mh) & $0,22,651$ & 0.978 & 0.7286 & 1.12378 & 1.5364 & 0.359 & 1.80967 & 1.6577 & 0.3091 \\
\hline Kerkenah (kr) & 0.45942 & 1105 & 0.815 & 3.1549 & 2.852 & 0.9656 & 3.22185 & 2.613 & 0.9255 \\
\hline Jerba (je) & 0.22999 & 0.6712 & 0.6065 & 1.17457 & 1.6093 & 0.652 & 1.6216 & 1.5667 & 0.551 \\
\hline
\end{tabular}

$a b$ parameter of the allometric equations, $R^{2}$ coefficient of determination

The application of AFD clearly revealed the existence of significant differences between individuals from different samples. Interestingly, three main localities (Port Prince, Haouaria and Mahdia) showed the greatest gap from the origin of the axes (Fig.4). Samples from Port Prince were situated on the negative side of axe 1, while samples of Mahdia and Haouaria were located on both sides and positioned at the positive side of this axe. The arrangement revealed two groups: the first group enclosed Gammarth, Tabarka, Sounine, Ras Angela and Kelibia which overlaps with Port Prince and Haouria. The second, comprised Hergla, Monastir, Kerkena and Jerba which overlaps with Mahdia.

\section{Discussion}

In the Mediterranean P. lividus occupy divers habitats (Guidetti et al. 2004), but species favors boulders which provide mainly protection against waves and predation (Sala and Zabala 1996). On rock substrates, scattered with photophilic algae, $P$. lividus is frequently collected by amateur and professional. Morphometric relationships and somatic growth are the first steps which has used to establish and develop sustainable fishery of the species (Pancucci and Panayotis 1994; Gianguzza et al. 2006; Guinda et al. 2016).

The present survey is the first report on biometric characteristics of the P. lividus population from the coasts of Tunisia. Results revealed that linear and weight parameters, diameter (D), height $(\mathrm{H})$, total weight (TW) and total weight test (TWTE) were not homogenous among the different localities' samples. Significant and insignificant differences were observed between the thirteen selected localities.

Throughout the period of investigation, the samples' size distribution from the thirteen localities were not similar and diameter means were significantly different. Port Prince and Haouaria showed bimodal distribution, while a unimodal size frequency distribution was observed within all the other localities. Classical studies have documented that the different size classes of $P$. lividus could be associated to many characteristics such as: habitat (i.e., depth and substrate) (Guidetti et al. 2004), environmental conditions (i.e., water temperature, salinity, currents and pollution) (Fernandez et al. 2006) and biology and physiology of the species (Vafidis et al. 2019). The lack of some sea urchin size classes as well as the decreases in some frequencies may be associated with harvesting (Farina et al. 2018), which is specifically the case of the Ras Angela and Sounine localities where collection has been done. In this study, these localities displayed substantial changes within the population structure. However, harvesting pressure was also associated with the significant reduction in density and abundance of specimens (Guidetti et al. 2004; Bertocci et al. 2013; Ourens et al. 2014). In the absence of field data and since no major difference in species' abundance between the localities was observed during the sampling period, it is noteworthy to suggest that distribution size changes are likely mostly attributed to the fishing intensity, at least for the two locations of Ras Angela and Sounine.

All the diameter-weight relationships studied (D -TW) and (D -TWTE) followed a negative allometry in all the localities, with the exception of Gammarth who showed a positive somatic growth for the diameter total fresh weight relationship 
Fig. 3 Graphic representation of the different relationships a Height (H)-diameter (D), b total weight (TW) - (D) and c total weight test (TWTE) - (D) of Paracentrotus lividus from Tunisia coast

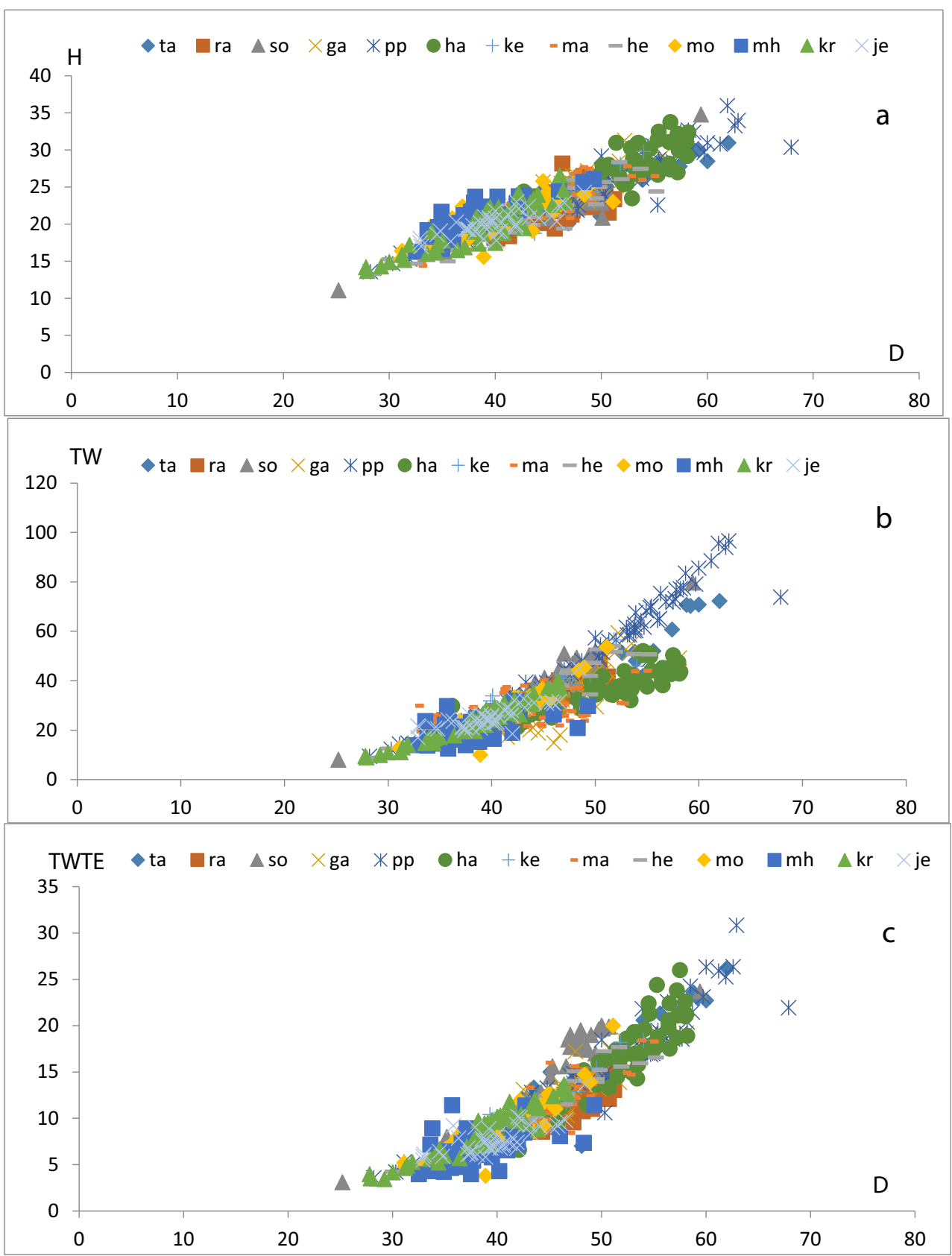

(D- TW). Such a negative growth pattern has also been reported in populations of $P$. lividus from other areas of the Mediterranean (Regis 1981). Likewise, in Sardinia Pais et al. (2006) and in Greece Antoniadou and Vafidis (2009), reported negative somatic growth similar to that encountered on the Tunisian coast.

However, the relationships D-H showed a spatial variation. This relationship, known as a flattening, is linked to somatic growth, which depends on environmental factors and particularly the food consumption (Guillou and Michel 1994; Fernandez and Boudouresque 1997; Sellem et al. 2000; Ourens et al. 2014). In the different localities examined growth rate shows values between 0.671 and 1.204 close to the values estimated for other Mediterranean regions (Regis 1981). In Greece, for example, growth coefficient of species has value of 0.87 (Antoniadou and Vafidis 2009), who is close to the locality of Monastir, while in Italy it is 1.035 , who is borders to the locality of Hergla. Finally, in Turkey Küçükdermenci and Lök (2014) report a growth coefficient of 0.526 adjacent to the locality of Jerba.

Overall, investigations discerned a dissimilarity of the thirteen samples within localities. The population of $P$. lividus seems heterogeneous, a clear discrimination is detected between the different samples and two groups of localities are highlighted. Similar observations were identified with FDA assemblages, which also indicated two sub-population groups 
Fig. 4 Factorial Discriminant Analysis (FDA): Barycentric representation of Paracentrotus lividus populations of $t a$ Tabarka, $r a$ Ras Angela, so Sounine, $g a$

Gammarth, $p p$ Port Prince, $h a$

Haouaria, ke Kelibia, $m a$

Maamoura, he Hergla, mo

Monastir, $m h$ Mahdia, $k r$

Kerkena, je Jerba

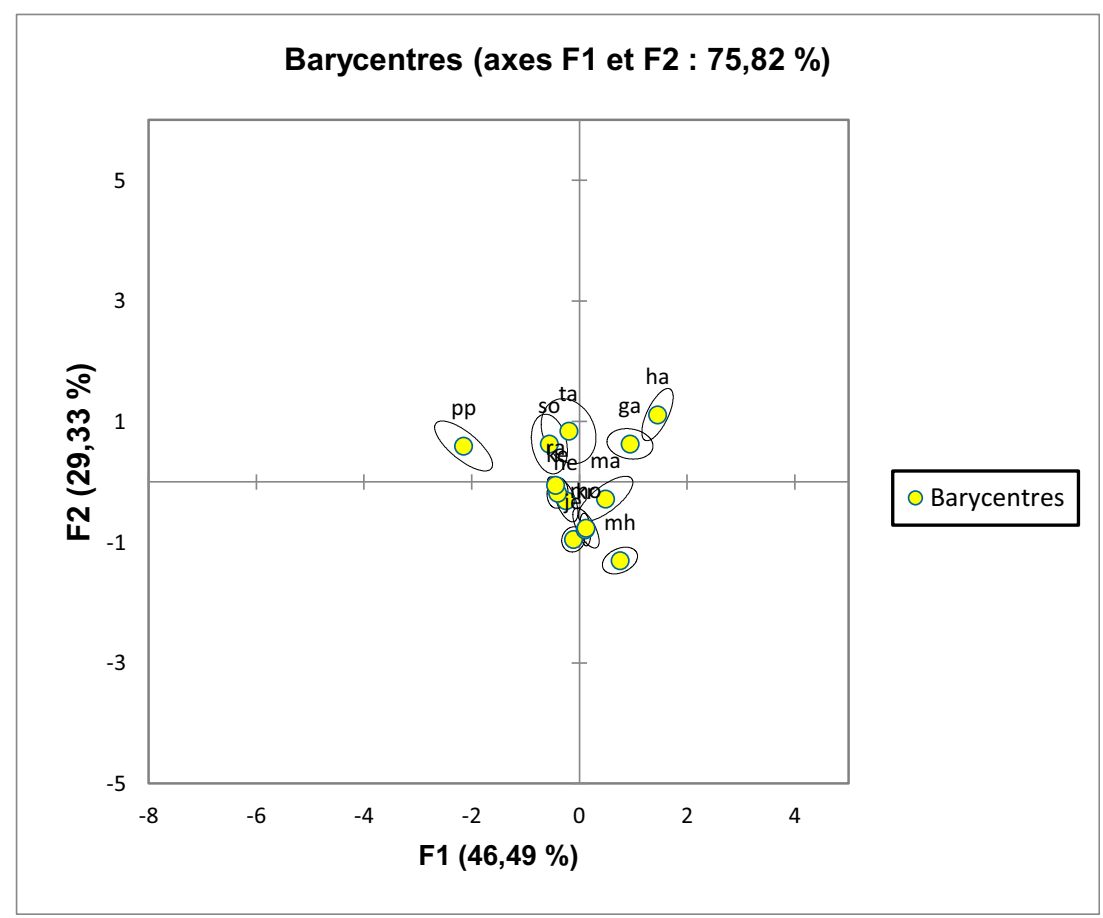

and which were matched to the geographical separation of the thirteen samples. In fact, subpopulation 1 included localities from the northern part of Tunisia (Tabarka, Ras Angela, Sounine, Gammarth, Port Prince and Haouaria) and subpopulation 2, contained localities situated from the eastern coast (Kelibia, Maamoura, Hergla, Monastir, Mahdia, Kerkena and Jerba). Finally, this investigation about biometric characteristics of the wild population of $P$. lividus allowed us to discern a metric and weight variation between populations from Tunisia shore and to describe two divergent groups assigned to two parts of the Mediterranean basin. This finding is in accordance with a previous study which reported a phenotypic divergence of Paracentrotus lividus across the SiculoTunisian Strait and a significant genetic differentiation between populations from the eastern and western Mediterranean (Deli et al. 2017).

The average values of linear and weight measurements showed significant differences between the northern and eastern localities of Tunisia. This is due to the different levels of the physical and chemical parameters of the waters as well as the physiology of the species. There are few sudies that underline size or weight variability of $P$. lividus in its habitat related to environmental factors but most studies, have shown an important relationship between somatic growth and the availability of food (Guillou and Michel 1994). Fernandez and Boudouresque (1997) revealed in Urbinu lagoon a morphometric variability of species related on the food quantity. In contrast, under eutrophication conditions Pancucci and Panayotis (1994) observed a smaller population of size in the Gulf of Amvrakikos.

In conclusion this preliminary study is the first one that investigated some morphological characteristics of $P$. lividus populations from Tunisia shore. Results shows that species has a plastic response in front of environnemental conditions. The biometric approch should be completed by further investigations especially availability of food consumption a key

Table 3 Statistical metric and weight comparison of Paracentrotus lividus with localities. The localities presenting the same letters form a group with significantly similar averages

\begin{tabular}{|c|c|c|c|c|c|c|c|c|c|c|c|c|c|}
\hline locality & $\mathrm{mh}$ & $\mathrm{kr}$ & mo & je & he & $\mathrm{ma}$ & $\mathrm{Ke}$ & so & $\mathrm{ra}$ & ga & ta & ha & $\mathrm{pp}$ \\
\hline \multicolumn{14}{|l|}{ variable } \\
\hline diameter (D) & $\mathrm{a}$ & $\mathrm{ab}$ & $a b c$ & $a b c$ & $a b c$ & bed & cde & def & ef & efg & fg & g & $\mathrm{g}$ \\
\hline height $(\mathrm{H})$ & $a b c$ & $\mathrm{a}$ & $a b c$ & $\mathrm{ab}$ & $a b c$ & abcd & bcd & bcd & $\mathrm{cd}$ & $\mathrm{e}$ & de & e & $\mathrm{e}$ \\
\hline total weight (TW) & $\mathrm{a}$ & $\mathrm{ab}$ & $\mathrm{ab}$ & $\mathrm{ab}$ & bcd & $a b c$ & cde & $\mathrm{e}$ & de & cde & e & cde & $\mathrm{f}$ \\
\hline total weight test (TWTE) & a & $a b c$ & $a b c$ & $\mathrm{ab}$ & $\mathrm{bc}$ & $\mathrm{bc}$ & $\mathrm{cd}$ & ef & $\mathrm{cd}$ & de & ef & ef & $\mathrm{f}$ \\
\hline
\end{tabular}

$a, b, c, d, e, f$, $g$ statistical significances, $t a$ Tabarka, $r a$ Ras Angela, so Sounine, ga Gammarth, $p p$ Port Prince, $h a$ Haouaria, $k e$ Kelibia, $m a$ Maamoura, $h e$ Hergla, mo Monastir, $m h$ Mahdia, $k r$ Kerkena, je Jerba 
factor controlling somatic growth and whose levels would change with physiology of the species.

Acknowledgements The authors warmly thank INSTM scientific diver A. Othman and are grateful to professor A. Rebai from Centre de Biotechnologie de Sfax for their advices on the statistical analyzes. The authors thank also the reviewers who improved a previous version of this paper.

Open Access This article is licensed under a Creative Commons Attribution 4.0 International License, which permits use, sharing, adaptation, distribution and reproduction in any medium or format, as long as you give appropriate credit to the original author(s) and the source, provide a link to the Creative Commons licence, and indicate if changes were made. The images or other third party material in this article are included in the article's Creative Commons licence, unless indicated otherwise in a credit line to the material. If material is not included in the article's Creative Commons licence and your intended use is not permitted by statutory regulation or exceeds the permitted use, you will need to obtain permission directly from the copyright holder. To view a copy of this licence, visit http://creativecommons.org/licenses/by/4.0/.

\section{References}

Antoniadou C, Vafidis D (2009) Population structure and morphometric relationships of Paracentrotus lividus (Echinodermata: Echinoidea) in the South Aegean Sea. Cah Biol Mar 50(4):293-301

Bayed A, Quiniou F, Benrha A, Guillou M (2005) The Paracentrotus lividus populations from the northern Moroccan Atlantic coast: growth, reproduction and health condition. J Mar Biol Assoc UK 85:999-1007

Ben Ismail S, Sammari C, Gasparini GP, Béranger K, Brahim M, Aleya L (2012) Water masses exchanged through the channel of Sicily: evidence for the 1 presence of new water masses on the Tunisian side of the channel. Deep-Sea Res 1(63):65-81

Bertocci I, Dominguez R, Machado I, Freitas C, Dominguez Godino J et al (2013) Multiple effects of harvesting on populations of the purple sea urchin Paracentrotus lividus in North Portugal. Fish Res 150:60-65. https://doi.org/10.1016/j.fishres.2013.10.010

Bulleri F (2013) Grazing by sea urchins at the margins of barren patches on Mediterranean rocky reefs. Mar Biol 160:2493-2501. https://doi. org/10.1007/s00227-013-2244-2

Crapp GB, Willis ME (1975) Age determination in the sea urchin Paracentrotus lividus (Lamarck) with notes on the reproductive cycle. J Exp Mar Biol Ecol 20:157-178

Deli T, Ben Attia MH, Zitari-Chatti R, Said K, Chatti N (2017) Genetic and morphological divergence in the purple sea urchin Paracentrotus lividus (Echinodermata, Echinoidea) across the African Mediterranean coast. Acta Oceanol Sini 36(12):52-66. https://doi.org/10.1007/s13131-017-1090-3

Ebert TA (1996) Adaptive aspects of phenotypic plasticity in echinoderms. Oceanol Acta 19:347-355

Elmasry E, Abdel Razek FA, El-Sayed AFM, Hamdy Omar H, Hamed ESAE (2015) Abundance, size composition and benthic assemblages of two Mediterranean echinoids off the Egyptian coasts: Paracentrotus lividus and Arbacia lixula. Egypt J Aquat Res 41: 367-374. https://doi.org/10.1016/j.ejar.2015.11.0101

Farina S, Quattrocchi G, Guala I, Cucco A (2018) Hydrodynamic patterns favouring sea urchin recruitment in coastal areas: a Mediterranean study case. Mar Environ Res 139:82-192. https://doi.org/10.1016/j. marenvres.2018.05.013
Fernandez C Boudouresque C F (1997) Phenotypic plasticity of Paracentrotus lividus (Echinodermata: Echinoidea) in a lagoonal environment. Mar Ecol Prog Ser 152:145-154

Fernandez C, Pasqualini V, Boudouresque CF, Johnson M, Ferrat L, Caltagirone A, Mouillot D (2006) Effect of an exceptional rainfsall event on the sea urchin (Paracentrotus lividus) stock and seagrass distribution in a Mediterranean coastal lagoon. Estuarine Coastal and Shelf Science 68(1-2):259-270

Gago J, Range P, Luís O (2003) Growth, reproductive biology and habitat selection of the sea urchin Paracentrotus lividus in the coastal waters of Cascais, Portugal. In Féral JP, David B (eds) Echinoderm research AA Balkema Lisse:269-276

Gianguzza P, Chiantore M, Bonaviri C, Cattaneo-Vietti R, Vielmini I, Riggio S (2006) The effects of recreational Paracentrotus lividus fishing on distribution patterns of sea urchins at Ustica Island MPA (Western Mediterranean Italy). Fish Res 81:37-44

Guettaf M, San Martin GA, Francour P (2000) Interpopulation variability of the reproductive cycle of Paracentrotus lividus (Echinodermata: Echinoidea) in south-western. Mediterranean J Mar Biol Ass UK 80:899-907

Guidetti P, Terlizzi A, Boero F (2004) Effects of the edible sea urchin, Paracentrotus lividus, fishery along the Apulian rocky coast (SE Italy, Mediterranean Sea). Fish Res 66:287-297

Guidetti P, Dulcic J (2007) Relationships among predatory fish sea urchin and barrens in Mediterranean rocky reefs across a latitudinal gradient. Mar Environ Res 63:168-184

Guillou M, Michel C (1994) The influence of environmental factors on the growth of Sphaerechinus granularis (Lamarck) (Echinodermata: Echinoidea). J Exp mar biol Ecol 178:97-11

Guinda X, Bidegain G, Puente A, Juanes JA (2016) A first approach to stock assessment of the sea urchin Paracentrotus lividus (Lamarck, 1816) in Cantabria (Bay of Biscay). J Mar Biol Assoc UK 97:1-10. https://doi.org/10.1017/S0025315416001521

Jacinto D, Bulleri F, Benedetti-Cecchi L, Cruz T (2013) Patterns of abundance, population size structure and microhabitat usage of Paracentrotus lividus (Echinodermata: Echinoidea) in SW Portugal and NW Italy. Mar Biol 160:1135-1146. https://doi.org/ 10.1007/s00227-013-2166-Z

Küçükdermenci A, Lök A (2014) Morphometric relationships and variability of annual body condition of sea urchin Paracentrotus lividus Echinodermata: Echinodermata at Foca coast in the South Aegean Sea. Fresenius Environ Bull 23(10):1-9

Lecchini D, Lenfant P, Planes S (2002) Variation in abundance and population dynamics of the sea-urchin Paracentrotus lividus on the Catalan coast (North-Western Mediterranean Sea) in relation to habitat and marine reserve. Vie et Milieu 52(2-3):111-118

Loi B, Guala I, Silva RP, Brundu G, Baroli M et al (2017) Hard time to be parents? Sea urchin fishery shifts potential reproductive contribution of population onto the shoulders of the young adults. PeerJ 5:e3067. https://doi.org/10.7717/peerj.3067

Lozano J, Galera J, López S, Turon X, Palacín C et al (1995) Biological cycles and recruitment of Paracentrotus lividus (Echinodermata: Echinoidea) in two contrasting habitats. Mar Ecol Prog Ser 122: 179-191

Ouréns R, Flores L, Luis Fernández L, Freire J (2013) Habitat and density-dependent growth of the sea urchin Paracentrotus lividus in Galicia (NW Spain). Journal of Sea Research 76:50-60

Ourens R, Freire J, Vilar JA, Fernandez L (2014) Influence of habitat and population density on recruitment and spatial dynamics of the sea urchin Paracentrotus lividus: implications for harvest refugia. ICES J Mar Sci 71:1064-1072. https://doi.org/10.1093/icesjms/fst201

Ourens R, Naya I, Freire J (2015) Mismatch between biological, exploitation, and governance scales and ineffective management of sea urchin (Paracentrotus lividus) fisheries in Galicia. Mar Policy 51: 13-20. https://doi.org/10.1016/j.marpol.2014.07.015 
Pais A, Chessa LA, Serra S, Meloni G, Ruiu A, Manunza B (2006) Morphometric relationships and annual gonad index of the edible sea urchin Paracentrotus lividus from north western Sardinia biol. Mar Medit 13(2):202-203

Pancucci MA, Panayotis A (1994) Impact of eutrophication on sea urchin populations of the Amvrakikos gulf (Ionian Sea, Greece) final reports on research projects dealing with eutrophications problems. MAP Technical Reports Series No 78:75-90

Regis MB (1981) Aspects morphométriques de la croissance de deux échinoides du golfe de Marseille, Paracentrotus lividus et Arbacia lixula. Cah Biol Mar 22:349-370

Sala E, Zabala M (1996) Fish predation and the structure of the sea urchin Paracentrotus lividus populations in the NW Mediterranean. Mar Ecol Prog Ser 140:71-81

Sala E, Ballesteros E, Dendrinos P, Di Franco A, Ferretti F et al. (2012) The structure of Mediterranean rocky reef ecosystems across environmental and human gradients, and conservation implications. PLoS ONE | www.plosone.org 1 February 2012 | volume 7 | issue 2 | e32742

Sellem F, Langar H, Pesando D (2000) Age et croissance de l'oursin Paracentrotus lividus lamarck, 1816 (Echinodermata-Echinoidea) dans le Golfe de Tunis (Méditerranée). Oceanol Acta 23(5):607-613
Sellem F, Guillou M (2007) Reproductive biology of Paracentrotus lividus (Echinodermata: Echinoidea) in two contrasting habitats of northern Tunisia (south-East Mediterranean). J Mar Biol Ass UK 87:763-767

Sellem F, Chouba L, Bouhaouala-Zahar B, Rafrafi S, Guillou M (2011) Assessment of 16 months of Paracentrotus lividus (Echinodermata Echinoidea) exploitation along the northern Tunisia coastline in the SW Mediterranean. Life and Environment 61(1):49-57

Tomas F, Romero J, Turon X (2004) Settlement and recruitment of the sea urchin Paracentrotus lividus in two contrasting habitats in the Mediterranean. Mar Ecol Prog Ser 282:173-184

Turon X, Giribet G, López S, Palacín C (1995) Growth and population structure of Paracentrotus lividus (Echinodermata: Echinoidea) in two contrasting habitats. Mar Ecol Prog Ser 122:193-204

Vafidis D, Antoniadou C, Kyriakouli K (2019) Reproductive cycle of the edible sea urchin Paracentrotus lividus (Echinodermata: Echinoidae) in the Aegean Sea. Water 11:1029. https://doi.org/10. 3390/w11051029

Publisher's Note Springer Nature remains neutral with regard to jurisdictional claims in published maps and institutional affiliations. 